\title{
Environmental Assessment Law and Practice in Nigeria Towards Achieving the UN Sustainable Development Goals (UNSDGs) in the Country: Cases of SDGs 13 and 17
}

\author{
Edward T. Bristol-Alagbariya \\ Associate Dean \& Senior Multidisciplinary Lecturer, Faculty of Law, University of Port Harcourt, NIGERIA; \\ and Visiting Research Fellow, Centre for Energy, Petroleum \& Mineral Law and Policy (CEPMLP), Graduate \\ School of Natural Resources Law, Policy \& Management, University of Dundee, Scotland, UNITED
} KINGDOM

\begin{abstract}
Environmental Assessment (EA) is an environmental protection, generic environmental governance and good governance tool by which the consequences of natural processes and human activities on the environment are predicted and evaluated, to minimise adverse consequences of proposed development project-proposals and maximise positive consequences of the proposals, in order to ensure qualitative environment and social equity, so as to achieve Sustainable Development (SD). Thus, by its inherent nature, EA promotes beneficial environment, by protecting and managing the environment, and contributing to SD and thus the UN Sustainable Development Goals (UNSDGs) in sovereign states, especially developing countries like Nigeria, which are richly endowed with major natural resources but plagued by the resource-curse. Particularly, based on life-cycle assessment and strategic environmental assessment, EA, has the potential to address the ongoing global problem and challenge of climate change, by contributing to improved environmental protection and management of lifecycle development projects, especially major natural resources extractive industrial development projects, in resources-rich global states like Nigeria. This paper demonstrates how EA in the form of life-cycle development projects-level assessment (Environmental Impact Assessment) and Strategic Environmental Assessment in Nigeria can promote the objectives of the EA process and practice, towards achieving informed environmental decision-making, high environmental quality and social equity and high-profile benchmarked business responsibility and sustainability practices, in the effort towards SD and thus the achievement of UNSDGs, particularly Goals 13 and 17 of the UNSDGs (respectively captioned 'Climate Action' and 'Partnerships for the Goals') in the country.

Keywords: Environmental Assessment (EA), Strategic Environmental Assessment (SEA), Extractive Industrial Operations (EIOs), Petroleum Development Projects, Corporate Social Responsibility (CSR), Government Social Responsibility (GSR), Good Environmental Governance (GEG), Sustainable Development (SD) and the UN Sustainable Development Goals (UNSDGs).
\end{abstract}

DOI: $10.7176 / \mathrm{JLPG} / 92-07$

Publication date: December $31^{\text {st }} 2019$

\section{Introductory Background}

This paper examines the problem, inability or failure of Nigeria and many other resources-rich developing countries to achieve sustainable development (SD), ${ }^{1}$ and how Environmental Assessment (EA) may contribute to the resolution of this problem, by promoting sound and more informed environmental decision-making and decision-implementation processes, Good Environmental Governance (GEG) and overall good governance (GG) and SD, in the course of life-cycle assessment of petroleum development projects. Moreover, the paper examines how formal institutionalisation of strategic environmental assessment (SEA) in Nigeria may boost the assessment of lengthy project-level development proposals such as cumulative, multiple, multi-criteria, multisectoral, life-cycle and trans-boundary development projects, which may be national, multinational or regional development projects, towards the achievement of SD, particularly the UNSDGs, in the country and beyond.

\section{Global Efforts towards SD: From the UN Millennium Development Goals (UNMDGs) to the UN} Sustainable Development Goals (UNSDGs)

Efforts of the entire global community to achieve SD are principally being initiated, propagated and superintended over by the UN, to ensure the wellbeing of mankind and society at large within member-states of

\footnotetext{
Homepages of the UN on the UN Millennium Summit and the UN Millennium Declaration $<$ https://www.un.org/en/development/devagenda/millennium.shtml >; Office of the United Nations High Commissioner for Human Rights $(\mathrm{OHCHR})$ on the UN Millennium Declaration <https:/www.ohchr.org/EN/ProfessionalInterest/Pages/Millennium.aspx>; the UN Development Programme (UNDP), Millennium Goals $<$ https://www.undp.org/content/undp/en/home/sdgoverview/mdg_goals.html>; UNDP, Sustainable Development Goals (SDGs) $<$ https://www.undp.org/content/undp/en/home/sustainable-development-goals.html>; all Accessed 20 November, 2019.
} 
the UN. These efforts commenced from the landmark aspirational target (which is popularly known as the UNMDGs), to the extant monumental aspirational target (which is accordingly known UNSDGs). In the process, by its Resolution 53/202 of 17 December, 1998, the UN General Assembly (UNGA), decided to designate the fifty-fifth session of the GA, 'The Millennium Assembly of the UN', and to convene, as an integral part of the Millennium Assembly, a Millennium Summit of the UN. ${ }^{1}$

The UN Millennium Summit (UNMS) took place from Wednesday, 6 September, to Friday, 8 September, 2000, at UN Headquarters, in New York. This Summit was attended by 149 Heads of State and Government and other high-ranking government officials from over 40 other countries. The main document that was unanimously adopted by the UNMS was the UN Millennium Declaration, which contained a statement of values, principles and objectives comprising an international agenda for the $21^{\text {st }}$ Century. The Summit also set deadlines for many collective actions by countries and people around the globe. Among other things, world leaders gathered at the UNMS committed their countries and people to objects and purposes of the UN, particularly towards achieving SD in the $21^{\text {st }}$ Century, and thus a new global partnership among countries and people of the world, to reduce extreme poverty and thereby improve human wellbeing, towards a fairer, more just, sustainable and peaceful world. Thus, the Summit framed a series of time-bound Goals, popularly known as the Millennium Development Goals (MDGs), which are to be achieved by the target year, 2015. ${ }^{2}$ The MDGs, which are eight in number, are as follows: Goal 1 (Eradicate Extreme Hunger and Poverty); Goal 2 (Achieve Universal Primary Education); Goal 3 (Promote Gender Equality and Empower Women); Goal 4 (Reduce Child Mortality); Goal 5 (Improve Maternal Health); Goal 6 (Combat HIV/AIDS, Malaria and other diseases); Goal 7 (Ensure Environmental Sustainability); and Goal 8 (Develop a Global Partnership for Development). ${ }^{3}$

As nations and people of the world, particularly those of developing countries, were unable to achieve the MDGs by the target year (2015), the global community, under the auspices of the UN, strove to introduce the Sustainable Development Goals (SDGs). On this note, by virtue of the UNGA Resolution 70/1, adopted on 25 September, 2015, captioned 'Transforming our world: the 2030 Agenda for Sustainable Development', member states of the UN, adopted a set of 17 Goals, popularly known as the SDGs, a universal call to action, designed to end poverty, protect the planet, and ensure peace and prosperity for all as part of a new SD agenda. ${ }^{4}$ The SDGs, described as .Global Goals', constitute a blueprint to achieve a better and more sustainable future for all. ${ }^{5}$ The Goals address the global challenges confronting humanity, countries and society at large, such as poverty, inequality, climate change, environmental degradation, peace and justice. These 17 Goals are interconnected, and are meant to be achieved by the target year (2030), in order not to leave any country or people behind (without achieving them by the afore-said target year). ${ }^{6}$ Each of the 17 SDGs has specific targets to be achieved over a 15 year period (from 2015), and all sectors of society (i.e., everyone), namely government, the private sector, civil society and individuals, ought to accomplish their roles for these Goals to be achieved. The Goals are as follows: Goal 1 (NO POVERTY: End Poverty in all its forms everywhere); Goal 2 (ZERO HUNGER: End hunger, achieve food security and improved nutrition and promote sustainable agriculture); Goal 3 (GOOD HEALTH and WELLBEING: Ensure healthy lives and promote well-being for all at all ages); Goal 4 (QUALITY EDUCATION: Ensure inclusive and equitable quality education and promote lifelong learning opportunities for all); Goal 5 (GENDER EQUALITY: Achieve gender equality and empower all women and girls); Goal 6 (CLEAN WATER and SANITATION: Ensure availability and sustainable management of water and sanitation for all); Goal 7 (AFFORDABLE and CLEAN ENERGY: Ensure access to affordable, reliable, sustainable and modern energy for all); Goal 8 (DECENT WORK and ECONOMIC GROWTH: Promote sustained, inclusive and sustainable economic growth, full and productive employment and decent work for all); and Goal 9 (INDUSTRY, INNOVATION and INFRASTRUCTURE: Build resilient infrastructure, promote inclusive and sustainable industrialization and foster innovation). The rest of the Goals are Goal 10 (REDUCED INEQUALITIES: Reduce inequality within and among countries); Goal 11 (SUSTAINABLE CITIES and COMMUNITIES: Make cities and human settlements inclusive, safe, resilient and sustainable); Goal 12 (RESPONSIBLE CONSUMPTION and PRODUCTION: Ensure sustainable consumption and production patterns); Goal 13 (CLIMATE ACTION: Take urgent action to combat climate change and its impacts); Goal 14

\footnotetext{
1 UN, 'Conferences, Meetings and Events: Millennium Summit (6-8 September $<$ https://www.un.org/en/events/pastevents/millennium_summit.shtml $>$ Accessed 20 November, 2019.

${ }^{2}$ Ibid.

UN, 'Millennium Development Goals and Beyond 2015: News on Millennium Development Goals' $<$ https://www.un.org/millenniumgoals/> Accessed 20 November, 2019.

${ }^{4}$ UNGA, 'Resolution adopted by the General Assembly on 25 September 2015 70/1: Transforming our world: the 2030 Agenda for Sustainable Development' <https://www.un.org/ga/search/view doc.asp?symbol=A/RES/70/1\&Lang=E > ; UN, 'A/RES/70/1 Transforming our world: the 2030 Agenda for Sustainable Development 21 Oct 2015, $<$ https://sustainabledevelopment.un.org/index.php?page=view\&type=111\&nr=8496\&menu=35>; UNDP, UN SDGs (n1). ${ }^{5}$ UNDP, SDGs (n1).

UNDP, SDGs (n1).

Development
}

Goals'<https://www.un.org/sustainabledevelopment/sustainable-development-goals/> Accessed 20 November, 2019. 
(LIFE BELOW WATER: Conserve and sustainably use the oceans, seas and marine resources for sustainable development); Goal 15 (LIFE ON LAND: Protect, restore and promote sustainable use of terrestrial ecosystems, sustainably manage forests, combat desertification, and halt and reverse land degradation and halt biodiversity loss); Goal 16 (PEACE, JUSTICE and STRONG INSTITUTIONS: Promote peaceful and inclusive societies for sustainable development, provide access to justice for all and build effective, accountable and inclusive institutions at all levels); and Goal 17 (PARTNERSHIPS for the GOALS: Strengthen the means of implementation and revitalise the Global Partnership for Sustainable Development). ${ }^{1}$

\section{The Need for Proper Management of Development Projects, EA, GEG, SD and the UNSDGs}

The introductory background indicates that this paper is aimed at methodically examining how the proper management of development projects generated certain key tools, one of which is EA, in order to promote GEG, as an aspect of all-embracing good governance (GG), towards achieving SD, and thus the UNSDGs. Consequently, it is important to mention that the need for proper management of adverse effects of development proposals, by protecting the environment, conservation of natural resources and overall nature, generated various national and international approaches. These approaches include environmental and developmental policies, laws, regulations, guidelines and standards, involving the use of specific environmental management tools, processes and practices, one of which is EA. ${ }^{2}$

Environmental Impact Assessment (EIA), also referred to as development project-level EA, is a form of EA EA, which may be used interchangeably with EIA, regulates the adverse effects of developmental proposals on the environment and society at large, towards GEG, achievement of SD and thus the UNSDGs. EIA is the systematic, reproducible, multi-disciplinary identification, prediction, evaluation, mitigation and management of impacts from a proposed development proposal and its reasonable and logical alternatives. ${ }^{3}$ EIA is the oldest and most well established form of EA. Formal or statutory EIA started in the USA with the enactment of the US National Environmental Policy Act (NEPA) of 1969/1970. From then, the concept and practice of formal EIA began to spread to other countries. Formal EIA commenced in Nigeria in 1992, after the UN Conference on the Environment and Development (UNCED - 'The Rio de Janeiro Earth Summit'), ${ }^{4}$ by virtue of Principle 17 of the Rio Declaration on Environment and Development, 1992, and the promulgation of the EIA Decree (Decree No. 86 1992). Principle 17 of the Rio Declaration on Environment and Development, 1992, provides that environmental impact assessment, as a national instrument, shall be undertaken for proposed activities that are likely to have a significant adverse impact on the environment and are subject to a decision of a competent national authority. ${ }^{5}$ The EIA Decree (Decree No. 86 1992), was eventually transformed into an Act of parliament and revised in 2004. Thus, the current EIA law in Nigeria, governing EA process and practice in the country, is the EIA Act $2004 .^{6}$

Formal EIA commenced in Nigeria in order to achieve the goals and objectives as well as generic steps or stages of EIA process and practice around the globe. Basically, the goals and objectives of formal EIA include to (i) identify significant environmental and other associated issues, ${ }^{7}$ which involve establishing the likely significant effects of development project proposals on the environment, which includes human wellbeing and the wellbeing of other species of nature and society at large; (ii) provide access to information (premised on information exchange among stakeholders), public participation in decision-making and access to justice, in environmental matters; (iii) minimise, mitigate or eliminate predicted adverse impacts of proposed development projects; (iv) address such predicted impacts through by appropriate follow-up, monitoring and environmental management mechanisms, and thereby verify the accuracy and effectiveness of mitigation measures designed to ameliorate them; and (v) generally minimise predicted adverse impacts of proposed development project-

\footnotetext{
Ibid.

${ }^{2}$ E. T. Bristol-Alagbariya, Participation in Petroleum Development: Towards Sustainable Community Development in the Niger Delta (Centre for Energy, Petroleum \& Mineral Law \& Policy [CEPMLP]/Dundee University Press [DUP] 2010) 138; E. T. Bristol-Alagbariya, Governance Towards Sustainable Development in Nigeria: The Role of Strategic Assessment of Decisions \& Actions (CEPMLP/DUP 2013) 73-74; E. T. Bristol-Alagbariya, 'On-the-Spot Appraisal EIA in Nigeria: Its Gradual Improvement Entailing the Development of Law and Practice' [2019] 11 (2) Journal of Property Law and Contemporary Issues, 131.

${ }^{3}$ Bristol-Alagbariya (2019 [n9]), 130; K. Nnadozie, 'Environmental Regulation of the Oil and Gas Industry in Nigeria' [2003] 36 International Environmental Law and Policy in Africa; 103-129; R. Ronchka, Environmental Impact Assessment: An Electric Utility Overview (E7 Network of Expertise for the Global Environment 1997); C. H. Eccleston, Environmental Impact Assessment: A Guide to Best Professional Practices (CRC Press 2011).

${ }^{4}$ UN, 'United Nations Conference On Environment and Development-UNCED (1992)' <https://www.unsystem.org/content/united-nationsconference-environment-and-development-unced-1992> Accessed 20 November, 2019; UN, 'United Nations Conference on Environment and Development (UNCED), Earth Summit'<https://sustainabledevelopment.un.org/milestones/unced $>$ Accessed 20 November, 2019.

${ }^{5}$ UN, 'A/CONF.151/26 (Vol. I) - Rio Declaration 12 Aug 1992: Report on the United Nations Conference on Environment and Development' $<$ https://sustainabledevelopment.un.org/index.php?page=view\&type=111\&nr=1709\&menu=35> Accessed 20 November, 2019; UNGA, Report of the United Nations Conference on Environment and Development (Rio de Janeiro, 3-14 June 1992)' $<$ https://sustainabledevelopment.un.org/content/documents/1709riodeclarationeng.pdf > Accessed 20 November, 2019.

${ }^{6}$ E. T. Bristol-Alagbariya (2019 [n9]), 132-133

${ }^{7}$ Section 3, EIA Act, Laws of the Federation of Nigeria (LFN) 2004, captioned 'Identification, etc., of Significant Environmental Issues'.
} 
proposals, so as to maximise positive impacts of the proposals. ${ }^{1}$ Regarding the generic steps or stages of the EIA in Nigeria, these stages are basically those of screening (which follows after proposal identification), scoping, impact analysis, mitigation and impact management, reporting, review, decision-making, implementation, involving monitoring and follow-up processes, as well as the auditing stage, which involves the commissioning, decommissioning, abandonment or closure stages of development project proposals. Nigeria's EIA procedural guidelines identify the stages of development proposals from project conception to commissioning stages, while the EIA sectoral guidelines for oil and gas industry projects further provide for remediation plans after decommissioning, closure or abandonment. Although detailed steps in EIA vary from country to country or jurisdiction to jurisdiction, the foregoing generic steps of the assessment process and practice in Nigeria are widely recognised and followed internationally. ${ }^{2}$

Undoubtedly therefore, EA/EIA/IA is generally considered as a tool for informed decision-making towards qualitative environment and social equity, so as to achieve SD and thus the UNSDGs. EA is a key tool for SD, and this is more so with strategic environmental assessment (SEA), which is a higher-tier, order or system of EA. SEA evolved in the 1980s as a systematic process for evaluating the environmental effects at strategic levels of decision-making: policies, plans and programmes, including projects (PPPs). ${ }^{3}$ SEA is a more suitable process for appraising lengthy (such as cumulative/life-cycle) project-level development proposals, including such other development proposals which are cumulative, multiple projects, multi-criteria, multi-sectoral, trans-boundary and multinational or regional in nature. ${ }^{4} \mathrm{SEA}$ is however yet to be formally institutionalised through legislative mechanism in Nigeria. Nigeria's federal legislative arm of government is thus yet to enact an SEA law, to complement the prevailing EIA process and practice in the country. ${ }^{5}$

Extractive industry operations (EIOs), namely petroleum (oil and gas) and other mining and mineral resources industrial development projects, play significant leading roles in the development and growth of EA/IA process and practice. Although EIOs inhibit SD, these operations can be advantageous when they are implemented well and preserve the rights of people who are directly affected by these projects, and if the benefits they generate are well-used.

Efficient cumulative or life-cycle EIA process has the advantage of maximising benefits of EA process and practice of development projects from cradle (projects conception) to grave (associated with decommissioning and abandonment, which involve environmental remediation and restoration of areas) of projects. Decommissioning of petroleum and other EIO projects involve the physical removal and disposal of obsolete installations at the end of the life-span of development projects, so as to remediate and restore the natural environment of each project area to its near pre-project state. ${ }^{6}$

\section{International SD-Oriented Efforts and the Roles of Government and Extractive Industries (EIs), such as Multinational Oil Companies (MNOCs)}

The discussion generated from the foregoing sub-heading is centred on the following: Global and international SD-oriented efforts and the significant roles of government, especially government regulatory agencies and EIs, such as MNOCs. The report of the World Commission on Environment and Development (WCED), otherwise known as the Brundtland Commission, defines SD as the development that meets the needs of the present generation of humanity without compromising the ability of future generations to meet their own needs. The Earth Charter Initiative, which advocates the values and principles of a sustainable future, highlights that SD expands our vision towards ethical or greater ethical principles and practices. ${ }^{7}$

\subsection{Aspects, Principles, Indicators and Other SD-Oriented Strategies and Initiatives}

SD has its aspects, principles, indicators and strategies as well as other SD-oriented initiatives. The aspects (i.e., spheres, components or pillars) of SD are economic, socio-cultural, environmental and governance spheres. Among these spheres of SD, the governance sphere, namely the role of good governance is very significant and key. It is on this note that the report of the World Commission on Environment and Development (WCED), popularly known as the Brundtland Commission, entitled Our Common Future succinctly cautions and echoes

\footnotetext{
${ }^{1}$ E. T. Bristol-Alagbariya (2019 [n9]), 133; Section 1, EIA Act, LFN 2004, captioned 'Goals and Objectives of Environmental Impact Assessment'.

${ }^{2}$ E. T. Bristol-Alagbariya (2019 [n9]), 133.

${ }^{3}$ Homepage of the International Association for Impact Assessment (IAIA) $<$ https://www.iaia.org/> Accessed 20 November, 2019.

${ }^{4}$ R. Therivel, Strategic Environmental Assessment in Action (Earthscan 2010), 19-21; E. T. Bristol-Alagbariya (2013 [n9]), 89-92 and 95-96; B. Sadler, et al (eds), Handbook of Strategic Environmental Assessment (Earthscan 2011); I. Linkov and E. Moberg, Multi-Criteria Decision Analysis: Environmental Applications and Case Studies (CRC Press 2017).

${ }^{5}$ National Assembly, A Bill for an Act to Repeal the Environmental Impact Assessment Act, Cap. E12 Laws of the Federation of Nigeria (LFN) 2004 (National Assembly Press 2018); L. Cosmas, 'Reps C'tte Hold Public Hearing on Environmental Assessment Act' $<$ https://aljazirahnews.com/reps-ctte-hold-public-hearing-environmental-assessment-act/> Accessed 20 November, 2019.

${ }^{6}$ E. T. Bristol-Alagbariya (2013 [n9]), 134-139.

${ }^{7}$ Homepage of the Earth Charter Initiative <https://earthcharter.org/> Accessed 20 November, 2019.
} 
that 'in the final analysis, sustainable development must rest on political will', ${ }^{1}$ while the Seventh UN SecretaryGeneral, Kofi Annan, succinctly remarks that 'good governance and SD are indivisible'.2

The principles of SD, which are outlined in Nigeria's policy on the environment, underscore the fact that the success of SD must be built on SD principles. ${ }^{3}$ These principles are namely (i) Precautionary Principle; (ii) Pollution Prevention Pays Principle (3P+); (iii) Polluter Pays Principle (PoPP); (iv) User Pays Principle (UPP); (v) Principle of Intra-Generational Equity; (vi) Principle of Inter-Generational Equity, and (vii) Principle of Participation (Environmental Democracy). These principles convey the links between development processes, environmental factors, humanity and natural resources. ${ }^{4}$

Concerning SD Indicators (SDIs), it may be mentioned that an indicator is an index, or a device, hint, flashlight, mark, pointer, or even a sign, which specifies or shows information about the condition or state of something. ${ }^{5}$ It is a device or an instrument for measuring the dimension of something, based on set standard. ${ }^{6}$ SDIs are used to evaluate (assess) and monitor ongoing SD initiatives. They are used to examine the efficacy of SD initiatives. SDIs provide an overview of progress towards a SD in all aspects and ramifications. Several categories of SDIs translate into wellbeing of citizens and the general public in society eg sovereign state/country. ${ }^{7}$ For instance, the UK Government list the following 68 indictors vis-à-vis wellbeing measures. These are Sustainable Consumption and Production (SCP), Climate Change and Energy (CCE), Natural Resource Protection and Enhancing the Environment (NRP), Creating Sustainable Communities and a Fairer World (CSC), Greenhouse Gas Emissions (Carbon dioxide Emissions by End User, Aviation and Shipping Emissions), Electricity Generation (Electricity Generation including Electricity by Renewable Energy), Carbon dioxide and other Emissions (Household Energy Use, Road Transport, Private Cars, Road Freight, Manufacturing Sector, Service Sector, and Public Sector), Resource Use (Resource Use, Energy Supply, Water Resource Use, Domestic Water Consumption, and Water Stress), and Waste (Waste, and Household Waste per person). Others are Natural Resources (Bird Populations, Biodiversity Conservation, Agriculture Sector, Farming and Environmental Stewardship, Land Use, Land Recycling, Dwelling Density, Fish Stocks, Ecological Impacts of Air Pollution, Emission of Air Pollutants, River Quality, and Flooding), Contextual Indicators (Economic Growth, Productivity, Investment, Demography, and Households and Dwellings). The rest are Society (Active Community Participation, Crime, and Fear of Crime), Employment and Poverty (Employment, Workless Households, Economically Inactive, Childhood Poverty, Young Adults, Pensioner Poverty, and Pension Provision), Education (Education, and Sustainable Development Education), Health (Health Inequality, Healthy Life Expectancy, Mortality Rate, Smoking, Childhood Obesity, and Diet), Mobility and Access (Mobility, Getting to School, Accessibility, and Road Accidents), Social Justice/Environmental Equality (Social Justice, Environmental Equality, Air Quality and Health, Housing Conditions, Household Living in Fuel Poverty, Homelessness, Local Environment Quality, Satisfaction in Local Area), International (International Assistance/International Aid), and Wellbeing. ${ }^{8}$

Wellbeing Measures may include Fear of Crime (including Perception of Anti-Social Behaviour), Workless Households, Childhood Poverty, Pensioner Poverty, and Education), Healthy Life Expectancy (Self-Reported General Health Status, and Self-Reported Long-Standing Illness), Mortality Rate (Suicide, Mortality Rate for those with Severe Mental Illness), Accessibility, Social Justice, Environmental Equality, Housing Conditions, Satisfaction with Local Area (Trust in people in Neighbourhood, and Influencing Decisions in the Local Area), Wellbeing (Overall Life Satisfaction, Overall Satisfaction with Aspects of Life, Positive and Negative Feelings, Engagement in Positive Activities, Child Wellbeing (Local Environment, Positive and Negative Feelings, Feelings of Safety, Health and Physical Activity, and Bullying), Physical Activity, Green Space, Cultural Participation, and Positive Mental Health). ${ }^{9}$

All SDIs, strategies and initiatives contribute collectively as well as in one way or another, to human wellbeing. Wellbeing is a broad concept, which may be defined and/or described severally. It may be construed as positive physical, social, economic, psychological, spiritual and medical etc. state of an individual or group. It

\footnotetext{
${ }^{1}$ The WCED, Our Common Future (Oxford University Press 1987), 9.

2 K. Annan, 'International Conference on Governance for Sustainable Growth and Equity', New York, 28-30 July, 1997 <http://www.pogar.org/publications/other/undp/governance/annan-address-e.pdf> Accessed 20 November, 2019; K. Ginther et al, (eds), Sustainable Development and Good Governance (Martinus Nijhoff Publishers 1995).

${ }^{3}$ Federal Environmental Protection Agency (FEPA), Revised National Policy on the Environment (FEPA 1999$) 1$.

${ }^{4}$ Ibid.

${ }^{5}$ Oxford.lexico.com, 'Indicator' < https://www.lexico.com/en/definition/indicator> Accessed 20 November, 2019; B. A. Garner (ed), Black's Law Dictionary (West Publishing 1999), 776

${ }^{6}$ Encyclopaedia Britannica, 'Gauge'< https://www.britannica.com/science/ecological-validity> Accessed 20 November, 2019.

7 UK Office for N National Statistics, Indicators' $<$ https://www.ons.gov.uk/peoplepopulationandcommunity/wellbeing/datasets/sustainabledevelopmentindicators> Accessed 20 November, 2019.

${ }^{8}$ The UK Department for Environment, Food and Rural Affairs (DEFRA), Sustainable Development Indicators in Your Pocket 2009: An Update of the UK Government Strategy Indicators (DEFRA 2009), 119.

${ }^{9}$ Ibid, 119-123.
} 
involves comfortability, good health, happiness, prosperity and a prospective future. It involves not just the absence of pain, discomfort and incapacity; it requires that individuals are able to meet their basic needs. Wellbeing suggests that people have a sense of purpose, and they are able to meaningfully participate in society as well as achieve their important goals in life. To the individual therefore, wellbeing may be enhanced by conditions that include supportive personal relationships, strong and inclusive communities, good health, financial and personal security, rewarding employment, and a healthy (i.e., safe and secured) and attractive environment. This is why wellbeing is integral to SD. Indeed, wellbeing cannot be fully measured by any single indicator, as there are numerous factors or combination of factors that engineer or are relevant to an individual's wellbeing. It is only possible to identify and measure some of these indicators that affect or influence an individual's or a group of people's wellbeing. This is why some regard SDIs as indicators that measure the immeasurable. ${ }^{1}$

\subsection{Global and Other International SD-oriented Efforts and the Roles of Government and MNOCs}

This aspect of the paper explores global and other international SD-oriented efforts and the role of government and MNOCs. It considers EA of petroleum development projects as examples of EIOs and the UNSDGs, which generates discussion on ongoing global and other international SD-oriented efforts and the key role of government and MNOCs. The examples considered are the Global EIOs sector's regulatory mechanisms, the World Business Council for SD (WBCSD), the UN Global Compact, Sustainable Energy for All (SEforALL), the UN SRJR process (i.e., UN Stockholm, Rio de Janeiro, Johannesburg and Rio de Janeiro Conferences on the environment and development and their ongoing processes) designed to achieve SD, and International Finance Corporation (IFC) sustainability framework, exemplified by the IFC performance standards on environmental and social sustainability.

The need for Nigeria and other resources-rich developing countries to exploit their abundant natural resources and vitalise other areas of their political economy, as they lacked capital, technology and skilled manpower, including managerial capabilities, make these countries to enter into economic development agreements (EDAs) with foreign investors like Multinational Companies (MNCs). In the course of petroleum development, the EDAs entered into between Nigeria and foreign investors of Nigeria's petroleum development operations (the MNOCs), range from earlier traditional concessions agreements (TCAs) to equity participation agreements (EPAs) such as Production Sharing Contracts (PSCs), Risk Service Contracts (RSCs) and Joint Venture Agreements [JVAs]). EPAs are improvements on TCAs.

Based on Nigeria's EIA 2004, and what obtains in practice, development proposals, projects or activities of any public or private sector organisation or institution of the Nigerian economy which may likely or to a significant extent affect the environment, are to be subjected to EIA. Consequently, the EIA process distinguishes three types of projects, namely: (a) mandatory study activities; ${ }^{2}$ (b) cases where EA is required; ${ }^{3}$ and (c) projects excluded from the EA process. ${ }^{4}$ Based on Section 12 of Nigeria's EIA Act, 2004, captioned 'Mandatory Study List not to be Carried out without the Report of the Agency', and the Schedule to this Act (associated with Section 12 of the Act), entitled 'Mandatory Study List Activities', petroleum (i.e., oil and gas projects) constitute one of the categories of development projects in the country, during which EIA is mandatory.

To secure capital outside Nigeria, MNOCs usually approach international finance institutions such as the IFC and other equator principles (EPs) compliant banks as the multilateral investment guarantee agency (MIGA). Equator Principles Financial Institutions (EPFIs) apply EPs to new projects (of all industrial sectors and globally) financed by four financial products, namely project finance advisory services, project finance, project-related corporate loans, and bridge loans. These principles are primarily intended to provide minimum standards for due diligence and monitoring, so as to support responsible risk decision-making. Member of the EPFIs belong to the Equator Principles Association (EPA), which is an unincorporated Association formed in July 2010. The objectives of the Association are to ensure easy coordination and overall management of its members, and smooth administration, management and development of the EPs. ${ }^{5}$ MIGA offers political risk insurance and credit enhancement guarantees to investors and lenders, so as to protect foreign investments countries. ${ }^{6}$ These institutions have some SD-oriented international benchmarked policies, standards, guidelines, procedures,

\footnotetext{
${ }^{1} \mathrm{Ibid}$; Economic and Social Research Council (ESRC) Group on Wellbeing in Developing Countries (WeD), Centre for Development Studies, University of Bath, Somerset, England, United Kingdom, 'Working Papers' <http://www.bath.ac.uk/socpol/welldev/research/working.htm> Accessed 20 November, 2019; S. Bell and S. Morse, Sustainability Indicators: Measuring the Immeasurable? (Earthscan 2008).

${ }^{2}$ Section 12, EIA Act, LFN 2004, captioned 'Mandatory Study List not to be Carried out without the Report of the Agency'; Schedule (Section 12) EIA Act, LFN 2004, entitled 'Mandatory Study List Activities'; FEPA, Environmental Impact Assessment Procedural Guidelines (FEPA 1995), 8-11.

${ }^{3}$ Section 13, EIA Act, LFN 2004, captioned 'Cases where Environmental Assessment is required'.

${ }^{4}$ Section 14, EIA Act, LFN 2004, captioned 'Excluded Projects'

${ }^{5}$ The Equator Principles Association (EPA), 'Equator Principles' <https://equator-principles.com/ > Accessed 20 November, 2019.

${ }^{6}$ Homepage of MIGA < https://www.miga.org/> Accessed 20 November, 2019.
} 
processes and practices associated with them investing in projects such as petroleum and other EIs projects.

The SD-oriented international benchmarked regulatory standards and practices associated with EIOs, particularly petroleum development projects also include those of the global EIs sector's regulatory mechanisms, the WBCSD, UN Global Compact, and the UN SRJR process on the environment and development, which is aimed at achieving SD around the globe. EIOs are generally governed by regulatory frameworks of the global EIs sector, having such organisations as the Global Mining Guidelines Group (GMGG) ${ }^{1}$ the Global Mining Institute $^{2}$ and the Global Mining Sustainability framework (which develops collaboration partnerships to address mining industry challenges towards sustainable mining operations). ${ }^{3}$ For instance, the GMGG is a Canadian Institute of Mining, Metallurgy and Petroleum, which facilitates global mining collaboration on solutions to common industry problems, needs and technology through standards, guidelines and best practices. GMG operates on the five principles of inclusivity, collaboration, innovation, optimisation and technology. ${ }^{4}$ There are such research-based efforts of key stakeholder-groups of EIs as the Mining, Minerals and SD (MMSD) project of $2000,{ }^{5}$ and the World Bank Group Extractive Industries Review of 2000/2004, ${ }^{6}$ which are designed and/or directed to ensure the contributions of EIOs to SD.

The WBCSD, with its headquarters in Geneva, Switzerland, ${ }^{7}$ was founded by a Swiss Entrepreneur, Stephan Schmidheiny, when he was appointed Chief Adviser for business and industry to the UN Secretary General during the UNCED, 1992. It is a CEO-led organisation of about 200 of the world's forward-thinking international companies, which are connected to 60 national and regional business councils and partner organisations, working together to make business more successful and sustainable. It helps its membercompanies to be more successful and sustainable, by focusing on the maximum positive impacts for shareholders, the environment and societies. Its vision is to build a world where nine billion people of the Planet Earth are living well by $2050 .{ }^{8}$ It designed a science-based approach and targeted business solutions to address the impacts of business by aspiring to realise the UNSDGs through transformational programmes. Although its membership cuts across several sectors of the global economy, which include the petroleum sector, and spread over six continents (i.e., Europe (47\%), Asia (24\%), North America (21\%), Latin America (5\%), Middle East $(2 \%)$ and Australia (1\%), ${ }^{9}$ MNOCs operating in Africa, particularly Nigeria are not listed as members of the WBCSD. Such as business council, which may be called BCSD in Nigeria, is needed, along with other strong, viable and efficient domestic institutions, in the ongoing efforts of Nigeria to achieve SD. ${ }^{10}$

Next is the UN Global Compact (a fall-out of ongoing economic globalisation premised on the UN system), which is the world's largest corporate voluntary sustainability initiative launched by the UN Secretary-General, in July 2000. ${ }^{11}$ By virtue of this Compact, private sector (business) around the globe is supporting the UN's effort towards SD, so as to benefit humanity, communities and markets around the world. Based on this Compact, companies are, at a minimum, required to strategically align with and operate in ways that conform to fundamental responsibilities premised on ten principles, in the areas of human rights, labour, environment and anti-corruption, and thereby enable them advance societal goals, and thereby upholding their basic responsibilities to humanity and the Planet Earth, towards ensuring their long-term success, wherever they are operating around the globe. ${ }^{12}$

The UN Global Compact features as an international benchmarked initiative regarding Corporate Social Responsibility (CSR), especially corporate environmental and social responsibilities, in comparison with the prevailing considerably inefficient and ineffective forms of CSR measures in Nigeria, which require improvement. Also, to promote CSR measures in Nigeria, there is the extant 'Code of Corporate Governance for Public Companies, which is organised and/or superintended over by the country's Securities and Exchange

\footnotetext{
${ }^{1}$ Homepage of the GMGG < https://gmggroup.org/> Accessed 20 November, 2019.

${ }^{2}$ Global Mining Institute <https://home.kpmg/xx/en/home/insights/2015/05/mining-news.html > Accessed 20 November, 2019.

${ }^{3}$ Homepage of Global Mining Sustainability <https://globalminingsustainability.com/> Accessed 20 November, 2019.

${ }^{4}$ GMGG, 'About Us'< <ttps://gmggroup.org/about-us/> Accessed 20 November, 2019.

${ }^{5}$ International Institute for Environment and Development (IIED) and WBCSD, Breaking New Ground: Mining, Minerals, and Sustainable Development: The Report of the MMSD Project (Earthscan 2002).

${ }^{6}$ World Bank Group, 'Striking a Better Balance - The World Bank Group and Extractive Industries: The Final Report of the Extractive Industries $\quad$ Review, World Bank Group Management $<$ http://documents.worldbank.org/curated/en/961241468781797388/pdf/300010GLB.pdf > Accessed 20 November, 2019.

${ }^{7}$ Homepage of the WBCSD <https://www.wbcsd.org/> Accessed 20 November, 2019.

${ }^{8}$ WBCSD, 'Our philosophy of open membership' https://www.wbcsd.org/Overview/Our-members> Accessed 20 November, 2019.

${ }^{9}$ WBCSD, 'Membership by sector: Membership by region'<https://www.wbcsd.org/Overview/Our-members $>$ Accessed 20 November, 2019.

${ }^{10}$ Goal 16, UN SD Goals (UNSDGs), captioned 'Peace, Justice and Strong Institutions'; D. Acemoglu and J. Robinson, The Role of Institutions in Growth and Development (The International Bank for Reconstruction and Development [IBRD]/The World Bank 2008); T. Jackson, Prosperity without Growth: Foundations for the Economy of Tomorrow (Routledge 2016); S. T. Powers et al, 'How Institutions Shaped the Last Major Evolutionary Transition to Large-Scale Human Societies' [2016] The Royal Society, 1-10.

${ }^{11}$ Homepage of the UN Global Compact <https://www.unglobalcompact.org/> Accessed 20 November, 2019; UN Global Compact, 'Who We Are'<https://www.unglobalcompact.org/what-is-gc> Accessed 20 November, 2019.

12 The UN Global Compact, 'The Power of Principles: The Ten Principles of the UN Global Compact' $<$ https://www.unglobalcompact.org/what-is-gc/mission/principles $>$ Accessed 20 November, 2019.
} 


\section{Commission. ${ }^{1}$}

Besides, SEforALL, mentioned above, is an international organisation working in partnership with governments (particularly leaders in government), the private sector, civil society and the UN system, to drive and ensure accelerated action towards the achievement of the UNSDG7, captioned 'Affordable and Clean Energy': Access to Affordable, Reliable and Sustainable Modern Energy for All, and the Paris Agreement, which calls for reducing greenhouse gas emissions to limit climate warming to below $2^{\circ}$ Celsius. SEforALL is a global platform, which empowers leaders and decision-makers to broker partnerships, as well as facilitates access to finance, so as to achieve universal access to affordable, reliable, sustainable and modern energy for all. SEforALL marshals evidence, benchmarked progress and connects stakeholders around the globe, in order to amplify voices advocating and relaying success stories that are being made towards providing access to affordable, reliable and sustainable modern energy for all humankind on Planet Earth, by $2030{ }^{2}$

The most robust global SD-oriented effort is the UN SRJR process, which refers to the UN Conference on the Human Environment (UNCHE), held at Stockholm, Sweden, in 1972 (following which the assembly of the world community took place in Nairobi, Kenya, from 10-18 May, 1982, when the UN Nairobi Declaration of 1982 was reached); the UNCED, held at Rio de Janeiro, Brazil, in 1992; the World Summit on SD (WSSD), held at Johannesburg, South Africa, in 2002; and the UN Conference on SD (UNCSD), held again in Rio de Janeiro, Brazil, in 2012, and the progressively ongoing processes of these conferences and summits. The initiative of the UN Secretary-General for setting-up the UN Global Compact, efforts of the WCED, the UN Environment Programme (UNEP) and the Division for SD Goals (DSDGs) in the UN Department of Economic and Social Affairs (UNDESA), which acts as Secretariat for the UNSD Goals (UNSDGs) in the UN system, are remarkable in the context of the UN SRJR process and its progressively ongoing processes. Fall-outs of the UN SRJR process and its ongoing processes are international benchmarked soft law regulatory mechanisms being implemented in Nigeria and other member-states of the UN. ${ }^{3}$

The IFC works with partners to establish principles for impact investing to enhance financial returns for the corporation and to help its investors achieve positive impacts for the wellbeing of society, including developing countries. ${ }^{4}$ Thus, the IFC sustainability framework consists of the IFC's policy on environmental and social sustainability, which defines IFC's commitments to environmental and social sustainability; the IFC's performance standards, which define responsibilities of IFC clients for managing their environmental and social risks; and the IFC's access to information policy. ${ }^{5}$ The IFC sustainability framework articulates the corporation's strategic commitment to SD, as an integral part of the IFC's approach to risk management. ${ }^{6}$ Among other resources, the IFC sustainability framework comprises eight performance standards on environmental and social sustainability, which IFC clients are to comply with throughout the life of an investment associated with it. These Performance Standards are namely Performance Standard 1 (on Assessment and Management of Environmental and Social Risks and Impacts); Performance Standard 2 (on Labour and Working Conditions); Performance Standard 3 (on Resource Efficiency and Pollution Prevention); Performance Standard 4 (on Community Health, Safety and Security); Performance Standard 5 (on Land Acquisition \& Involuntary Resettlement [including Economic Displacements]); Performance Standard 6 (on Biodiversity Conservation and Sustainable Management of Living Natural Resources); Performance Standard 7 (on Indigenous Peoples [including Aboriginal Groups]; and Performance Standard 8 (on Cultural Heritage). ${ }^{7}$ These performance standards, which apply to all IFC investments and advisory clients, define the responsibilities of IFC clients for managing their environmental and social risks. These standards provide guidance on how to identify risks and impacts, and are designed to help avoid, mitigate, and manage risks and impacts, to enhance development opportunities, as a way of doing business in a sustainable way. ${ }^{8}$

\footnotetext{
1 Securities and Exchange Commission, Nigeria, 'Code of Corporate Governance for Public Companies May 12, 2014' $<$ https://sec.gov.ng/code-of-corporate-governance-for-public-companies_may-12-2014/> Accessed 20 November, 2019.

${ }^{2}$ Homepage of SEforALL <https://www.seforall.org/>; SEforALL, 'About us' <https://www.seforall.org/about-us $>$ both Accessed 20 November, 2019

${ }^{3}$ E. T. Bristol-Alagbariya, Petroleum Development \& the Environment in Rivers State Nigeria: Fallouts of the UNEP Report on Ogoniland, Environmental Regulatory Standards \& Sustainable Development Laws \& Practices (LAP LAMBERT Academic Publishing 2018 ), 43.

${ }^{4}$ Homepage of the IFC $<$ https://www.ifc.org/wps/wcm/connect/corp_ext_content/ifc_external_corporate_site/home $>$ Accessed 20 November 2019; IFC, 'About IFC' $<$ https://www.ifc.org/wps/wcm/connect/corp_ext_content/ifc_external_corporate_site/about+ifc_new $>$ Accessed 20 November, 2019

${ }^{5}$ IFC, 'IFC Sustainability Framework' <https://www.ifc.org/wps/wcm/connect/topics_ext_content/ifc_external_corporate_site/sustainabilityat-ifc/policies-standards/sustainability+framework> Accessed 20 November, 2019.

$\begin{array}{lllllll}6 & \text { Ibid; } & \text { IFC, } & \text { 'IFC } & \text { Sustainability } & \text { Framework } & -\end{array}$ $<$ https://www.ifc.org/wps/wcm/connect/topics_ext_content/ifc_external_corporate_site/sustainability-at-ifc/policiesstandards/ifcsustainabilityframework 2012> Accessed 20 November, 2019.

${ }^{7}$ IFC, 'Performance Standards' < https://www.ifc.org/wps/wcm/connect/Topics_Ext_Content/IFC_External_Corporate_Site/SustainabilityAt-IFC/Policies-Standards/Performance-Standards/> Accessed 20 November, 2019.

8 IFC, IFC Performance Standards on Environmental and Social Sustainability Effective January 1, 2012 (IFC 2012) $<$ https://www.ifc.org/wps/wcm/connect/c02c2e86-e6cd-4b55-95a2-

b3395d204279/IFC Performance Standards.pdf?MOD=AJPERES\&CVID=kTjHBzk $>$ Accessed 20 November, 2019.
} 
Although the foregoing and other global and international soft law regulatory mechanisms are not compelling on countries like the hard laws of these countries, they are governing EIOs around the globe and thereby positively transforming domestic legal and institutional frameworks and practices of these states, in the ongoing era of SD. These soft law mechanisms are even increasingly having the compelling force and effects of hard laws in resources-rich developing countries. They are increasingly transforming developmental PPPS associated with the environment, towards (GEG in resources-rich developing countries like Nigeria and thereby enhancing GG and SD, centred on human wellbeing, towards a fairer, more just, sustainable and peaceful world. ${ }^{1}$

\subsection{Corporate Social Responsibility (CSR), Government Social Responsibility (GSR) and Social Responsibilities of Communities (SRCs) towards SD}

In order to discuss the roles of government and MNOCs indicated in the foregoing sub-heading, this sub-heading may commence by considering the roles of MNOCs, from the subject-matter of CSR, which is a broad, complex, versatile and increasingly dynamically-expanding subject from concept to cover. ${ }^{2}$

CSR may be discussed from the perspective of its different names, factors associated with its evolution, its aspects or dimensions, and views on its contribution to society in relation to the social responsibilities of multinational companies (MNCs) designed to complement GSR or inadequate GSR in the context of the impacts of business in society, especially the adverse consequences of business operations, such as major natural resources development EIOs in developing countries. ${ }^{3}$

The idea of CSR dates back to the 1930s. It was coined in 1953 by Howard R. Bowen in his book entitled Social Responsibilities of Businessmen. ${ }^{4}$ Its discourse may involve the use of a variety of terms, concepts, principles or names which include 'business ethics', 'corporate responsibility', 'corporate accountability', 'corporate voluntary or self-regulatory measures' (i.e., 'corporate self-regulation'), 'environmental stewardship', 'corporate philanthropy', 'corporate social/public investments or interventions', 'socially conscious investment', 'corporate social performance' and 'corporate citizenship'. Others are 'business for social responsibility', 'company obligations', 'public relations', 'community relations', 'economic, legal, ethical and discretionary responsibilities of companies', 'corporate paternalism', and 'corporate sustainability initiatives'. These terms reflect a wide range of issues, including business in relation to public scrutiny (i.e., the court of public opinion on business), business-society relationship, and in the particular context of this study - the effects of business, especially EIOs, on the environment, community development, poverty and human wellbeing in resources-rich developing countries like Nigeria. Also, increasing economic competition among MNCs, especially multinational extractive industries, is another reason accounting for the growth of CSR in developing countries, which are richly endowed with major natural resources, but plagued by the resource-curse. In effect, CSR evolved to sustain the operations of MNCs extracting major natural resources in poor, marginalised and crisesriven rural communities in developing countries, so as to complement GSR and to enhance SD of these resources, poverty alleviation, human wellbeing and sustainable community development (SCD). ${ }^{5}$

CSR evaluates how companies manage their core business to add value to stakeholders such as consumers and other members of society affected by their value-chain, in order to promote business sustainability and to contribute to SD. CSR is the enlargement of the social responsibilities of companies to members of the public, which are affected by the operations of companies. These may imply the increasing social intervention measures of the MNCs designed over and above what domestic laws and regulations provide in developing countries. CSR involves how business sustainability is intertwined with economic growth, social cohesion and environmental protection. It involves environmental, social, ethical, governance, health, human rights and other issues, in a way that its scope varies from country to country, region to region, and interest group to interest group, and so on. It examines the changing relationship between business, society, and government, environmental issues, corporate governance, the social and ethical dimensions of management, globalisation, stakeholder debates, shareholder and consumer activism, changing political systems and values, and the ways in which corporations can respond to new and dynamic social imperatives. In the course of CSR, companies improve on their social responsibility profile, by investing in socially and environmentally sound operations and thereby contribute towards the

\footnotetext{
${ }^{1}$ Homepage of the Earth Charter Initiative (n21).

${ }^{2}$ D. Chandler, Strategic Corporate Social Responsibility: Sustainable Value Creation (SAGE Publications, Inc. 2017); J. Moon, Corporate Social Responsibility: A Very Short Introduction (Oxford University Press 2014); W. Visser et al, The A to Z of Corporate Social Responsibility (John Wiley \& Sons 2008), especially 122-123; A. Crane et al (eds), The Oxford Handbook of Corporate Social Responsibility (Oxford University Press 2008); W. Visser, Business Frontiers: Social Responsibility, Sustainable Development and Economic Justice (Institute of Chartered Financial Analysts of India [ICFAI] University Press 2006); W. Visser et al (eds), Corporate Citizenship in Africa: Lessons from the Past, Paths to the Future (Greenleaf 2006); E. T. Bristol-Alagbariya (2010 [n9]), 196-197.

${ }^{3}$ E. T. Bristol-Alagbariya (2010 [n9]), 197.

${ }^{4}$ H. R. Bowen, Social Responsibilities of Businessmen (Harper \& Brothers 1953/University of Iowa Press 2013); E. T. Bristol-Alagbariya (2010 [n9]), 197.

${ }^{5}$ E. T. Bristol-Alagbariya (2010 [n9]), 197-198.
} 
wellbeing of humanity and society affected by their operations around the globe. ${ }^{1}$

CSR has internal and external aspects or dimensions. Internally, socially responsible practices involve employees in relation to the administration and management of company operations. The external dimension of CSR extends beyond the doors of a company to involve the company's wide range of stakeholders other than its employees. In a world of multinational investments, global production and supply chains, the list of company stakeholders is wider and far more embracing than the immediate operational area of the company. Thus, other stakeholders embraced in the course of CSR include the business partners and customers of companies, public authorities, and non-governmental organisations (NGOs) representing host communities and other affected local citizens' groups, including the environment in present and future generations of the host communities who may be endangered or otherwise adversely affected by the operations of companies. ${ }^{2}$

Although, there are myriads of rational criticisms of CSR measures being embarked upon by MNCs in developing countries, suffice here to state that these measures are basically voluntary self-regulatory mechanisms of companies, which are designed to complement lack of or inadequate GSR, ${ }^{3}$ in a manner that promotes business profit-making and sustainability strategies in developing countries. ${ }^{4}$

GSR arises from the social contract of governance, based on which the security and welfare of the governed are primary obligations, roles and responsibility of government. However, due to the absence of GG in developing countries, GSR is often weak or inadequate in these countries. Hence, there are clarion calls and agitation for GSR embedded in GG in developing countries. Consequently, it is significant to note that no matter how well designed or intended, and no matter how well implemented, CSR is not an alternative to GSR, ingrained in GG, in developing countries. Certainly, CSR is not an alternative to public sector government, particularly good and responsible public sector government (otherwise known as good governance [GG]) in developing countries like Nigeria. Precisely, simply and squarely, it is the duty of government to provide enabling environments for business, including MNCs, to operate and thrive. It is also the duty of government to properly regulate business organisations in the interest of public good or overriding public good in society; and governments of developing countries do not constitute any exception to accomplishing their duties in these forms. ${ }^{5}$

Next, it should be mentioned that in developing countries characterised by high profile CSR measures, there is a need for social responsibility of civil society groups, which are affected by operations of business or companies. Such civil society groups include oil producing communities of the Delta region of Nigeria. On this note, the existence or prevalence of GSR, CSR and Social Responsibilities of Communities (SRCs) may or should promote sustainable petroleum resources development in these communities, towards environmentallysound and socio-economically equitable sustainable community development (SCD) in the Delta region. ${ }^{6}$

By and large, in order to achieve the SDGs in Nigeria, the Office of the Senior Special Assistant to the country's President on the SDGs (OSSAP-SDGs) emphasises that all stakeholders, traversing the federal, states and local governments, as well as civil societies, academia, religious and political leaders and the media in Nigeria, must harmoniously work to guarantee that peace, justice and strong institutions exist at all levels of government in the Nigerian society, by the year $2030 .^{7}$ It is however pertinent to highlight that the 17 Goals outlined by the UN in the SDGs are the minimum for any global state to achieve before the target year (2030), and as such Nigeria's achievements of these Goals are to be holistic and should be rationally measured by SDIs rather than by virtue of any subjective evaluation or assessment process often embarked upon by government functionaries and agencies in the form of propaganda or subjective publicity. ${ }^{8}$

\section{Conclusion}

So far, the foregoing global and other international soft law regulatory mechanisms governing EIOs around the globe could be described as partnership efforts of private and public sectors (enshrined in Goal 17 of the UNSDGs), to promote the protection and improvement of the environment in the course of EIOs, so as to enhance SD in global states. These regulatory mechanisms are enhancing achievement of the UNSDGs, especially Goals 13 and 17 of the UNSDGs, respectively captioned 'Climate Action' and 'Partnerships for the Goals', including Goal 7 of the SDGs, captioned 'Affordable and Clean Energy', which is designed to ensure access to affordable, reliable, sustainable and modern energy for all (SEforALL) around the globe.

\footnotetext{
${ }^{1}$ Ibid, 198-199.

${ }^{2}$ Ibid, 199-200.

${ }^{3}$ D. A. Detomasi, 'The Political Roots of Corporate Social Responsibility' [2008] 82 (4) Journal of Business Ethics, $807-819$.

${ }^{4}$ E. T. Bristol-Alagbariya (2010 [n9]), 201-202.

${ }^{5}$ Ibid, 202.

${ }^{6} \mathrm{Ibid}, 28,31,35,331$ and 334.

${ }^{7}$ OSSAP-SDGs, 'Sustainable Development Goals (SDGs) - The Nigerian Way' <https://sdgs.gov.ng/sustainable-development-goals-sdgsnigerian-way/> Accessed 20 November, 2019

${ }^{8}$ UK Office for National Statistics (n28); The UK DEFRA (n29); S. Bell and S. Morse (n31); R. Nwaebuni, 'Goodbye MDGs, Welcome Sustainable Development Goals'<https://thepointernewsonline.com/?p=39981> Accessed 20 November, 2019.
} 
We recommend that Nigeria, based on the leading and regulatory roles of government (especially the FG), followed by the environmental and social responsibility roles of the private sector (businesses), Nigeria should promote the UNSDGs, so as to achieve them, towards environmentally-sound and socio-economically equitable SD in the course of EIOs in the country. In order to robustly domesticate the ideals and practices of the UN Global Compact, the WBCSD and other international benchmarked soft law business regulatory and sustainability standards and practices associated with energy resources and EIOs in Nigeria, we further recommend that government, especially government regulatory agencies, led by the Federal Ministry of Environment, should persuade EIs, such as MNOCs, to establish a BCSD in Nigeria. Considering the significant role of institutions towards achieving the UNSDGs, coupled with the existence of other relevant strong, competent and efficient institutions in Nigeria, the proposed BCSD has the potential of existing as a landmark CSR organisation and would thus boost improvement of CSR measures in the country, and thereby complement positive impacts of the prevailing Code of Corporate Governance for Public Companies. This state of affairs would further promote and invigorate corporate environmental and social performances, towards improved business responsibility and sustainability practices in Nigeria, towards high-profile benchmarked standards and practices of business responsibility and sustainability prevailing elsewhere around the globe. However, so far achieving any form of high-profile or international benchmarked Government Social Responsibility (GSR) and CSR standards and practices remains utopian in Nigeria, until these are actually achieved in the overall interest of humanity and the entire country, in ongoing efforts towards SD in the country.

We further recommend that Nigeria's achievements of the SDGs are to be holistic, pragmatic and based on sound assessment. Nigeria and other global states are, in effect, to achieve the entire 17 Goals outlined by the UN, which Goals constitute the minimum standard and within or before the specified target year (2030). Accordingly, we reiterate that Nigeria's efforts to achieve the SDGs should be strategically and rationally measured by SDIs, instead of any subjective assessment process, often rhetorically embarked upon by government officials and agencies in the form of propaganda or prejudiced publicity.

We also recommend that GSR and CSR efforts in Nigeria be embarked upon towards achieving international benchmarked GSR and CSR standards and practices in the country. Regarding improvement of corporate environmental and social responsibilities in Nigeria, we particularly recommend that international benchmarked soft law business regulatory and sustainability standards and practices be domesticated in conformity with pragmatic realities in the country, towards environmentally-sound and socio-economically equitable sustainable EIOs, especially environmentally-sound sustainable petroleum development operations, and overall sound and socio-economically equitable SD in Nigeria.

By integrating widely recognised and accepted international benchmarked soft law regulatory mechanisms into the EA process and practice of petroleum development and other EIOs' projects in Nigeria, it may be asserted that the existence of formal EA, institutionalised on the threshold of a vibrant domestic policy, strong, viable and efficient institutions, and good, dynamic and effective laws (including a robust SEA Act), which are enhanced by international benchmarked regulatory standards and practices, underscore the significant role of EA/EIA/IA as a tool for informed environmental decision-making, GEG and overall good governance (GG), towards achieving qualitative environment, social equity and SD, and thus the UNSDGS in the country. There is therefore a need for Nigeria to institutionalise SEA to accelerate the growth and advancement of EA towards more informed environmental decision-making and decision-implementation processes, GEG and overall GG, in order to achieve greater qualitative environment and social equity, in the efforts towards SD in the country.

Finally, the sub-heading of this paper on 'Corporate Social Responsibility (CSR), Government Social Responsibility (GSR) and Social Responsibilities of Communities (SRCs) towards SD' demonstrates the need for improved CSR and SRCs and a greater and more compelling need for GSR, which is inherent in GG, towards sustainable petroleum resources development operations and environmentally-sound and socio-economically equitable SCD in the oil-rich communities of the Delta region. We therefore recommend the improvement of CSR and SRCs and the enthronement of GSR, by ushering GG into play, in Nigeria.

\section{References}

Acemoglu D. and Robinson J., The Role of Institutions in Growth and Development (The International Bank for Reconstruction and Development [IBRD]/The World Bank 2008).

Bell S. and Morse S., Sustainability Indicators: Measuring the Immeasurable? (Earthscan 2008).

Bowen H. R., Social Responsibilities of Businessmen (Harper \& Brothers 1953/University of Iowa Press 2013).

Bristol-Alagbariya E. T., Governance Towards Sustainable Development in Nigeria: The Role of Strategic Assessment of Decisions \& Actions (Centre for Energy Petroleum \& Mineral Law \& Policy [CEPMLP]/Dundee University Press [DUP] 2013), 73-74, 89-92, 95-96.

Bristol-Alagbariya E. T., 'On-the-Spot Appraisal EIA in Nigeria: Its Gradual Improvement Entailing the Development of Law and Practice’ [2019] 11 (2) Journal of Property Law and Contemporary Issues, 130 133. 
Bristol-Alagbariya E. T., Participation in Petroleum Development: Towards Sustainable Community Development in the Niger Delta (Centre for Energy Petroleum \& Mineral Law \& Policy [CEPMLP]/Dundee University Press [DUP] 2010), 28, 31, 35, 43, 138, 196-202, 331, 334.

Crane A., McWilliams A., Matten D., Moon J. and Siegel D. S. (eds), The Oxford Handbook of Corporate Social Responsibility (Oxford University Press 2008).

Detomasi D. A., 'The Political Roots of Corporate Social Responsibility' [2008] 82 (4) Journal of Business Ethics, 807-819.

Eccleston C. H., Environmental Impact Assessment: A Guide to Best Professional Practices (CRC Press 2011).

Federal Environmental Protection Agency (FEPA), Revised National Policy on the Environment (FEPA 1999), 1. Garner B. A. (ed), Black's Law Dictionary (West Publishing 1999), 776.

Ginther, K., Denters, E. and de Waart, P. J. I. M. (eds), Sustainable Development and Good Governance (Martinus Nijhoff Publishers 1995).

Jackson T., Prosperity without Growth: Economics for a Finite Planet (Earthscan 2011).

Jackson T., Prosperity without Growth: Foundations for the Economy of Tomorrow (Routledge 2016).

Jackson T., Prosperity without Growth?: The Transition to a Sustainable Economy (Sustainable Development Commission 2009).

International Institute for Environment and Development (IIED) and World Business Council for Sustainable Development (WBCSD), Breaking New Ground: Mining, Minerals, and Sustainable Development: The Report of the MMSD Project (Earthscan 2002).

Linkov I. and Moberg E., Multi-Criteria Decision Analysis: Environmental Applications and Case Studies (CRC Press 2017).

Moon J., Corporate Social Responsibility: A Very Short Introduction (Oxford University Press 2014).

Powers S. T., van Schaik C. P. and L. Lehmann L., 'How institutions shaped the last major evolutionary transition to large-scale human societies' [2016] The Royal Society, 1-10.

Ronchka R., Environmental Impact Assessment: An Electric Utility Overview (E7 Network of Expertise for the Global Environment 1997).

Sadler B., Aschemann R., Dusik T., Fischer T., Partidario M. and Verheem R. (eds), Handbook of Strategic Environmental Assessment (Earthscan 2011).

Therivel R., Strategic Environmental Assessment in Action (Earthscan 2010), 19-21.

The UK Department for Environment, Food and Rural Affairs (DEFRA), Sustainable Development Indicators in Your Pocket 2009: An Update of the UK Government Strategy Indicators (DEFRA 2009), 119-123.

Visser W., Business Frontiers: Social Responsibility, Sustainable Development and Economic Justice (Institute of Chartered Financial Analysts of India [ICFAI] University Press 2006).

Visser W., McIntosh M. and Middleton C. (eds), Corporate Citizenship in Africa: Lessons from the Past, Paths to the Future (Greenleaf 2006).

Visser W., Matten D., Pohl M., and Tolhurst N., The A to Z of Corporate Social Responsibility (John Wiley \& Sons 2008), 122-123.

Visser W., McIntosh M. and Middleton C. (eds), Corporate Citizenship in Africa: Lessons from the Past, Paths to the Future (Greenleaf 2006).

Vogel D., The Market for Virtue: The Potential Limits of Corporate Social Responsibility (Brookings Institution 2005).

World Commission on Environment and Development (WCED), Our Common Future (Oxford University Press 1987), 9 . 